\title{
FAKTOR-FAKTOR YANG BERHUBUNGAN DENGAN LAYANAN KESEHATAN DI PEMUKIMAN KUMUH KELURAHAN KARUWISI KECAMATAN PANAKUKKANG MAKASSAR
}

\author{
Muh. Rifo Rianto ${ }^{1)}$ Syaifullah Cangara ${ }^{2)}$ Rahmat Muhammad $^{2)}$ \\ 1) Akademi Analis Kesehatan Muhammadiyah Makassar \\ 2) Pascasarjana Sosiologi, Universitas Hasanuddin \\ Alamat Korespondensi: riforianto@gmail.com
}

\begin{abstract}
Public health services in urban slums Karuwisi District of Makassar member a question into the background in this study_The aim of the research is to describe the utilization of health services and factors related to the utilization of health services in slum residential area. The research method is qualitative approach with a case study. The research instrument is an in-depth interview and document study in data collection. Informers are communities residing in the area of slum residence. The results of the research indicated that the community's responses on the symptoms or disease being suffered by them are varied, such as non-action, self-treatment, traditional remedy, modern health/private medication. Health service for the poor community enhances the efforts of the utilization of government health services, so that the community knows more about health services as a service needed urgently by poor community.
\end{abstract}

Keywords: health services, Slum residential area

\section{PENDAHULUAN}

Sistem pelayanan kesehatan merupakan bagian penting dalam proses peningkatkan derajat kesehatan. Dengan adanya sistem pelayanan kesehatan ini tujuan pembangunan kesehatan dapat tercapai secara efektif, efisien, dan tepat sasaran. Keberhasilan sistem pelayanan kesehatan sangat bergantung pada berbagai komponen yang ada baik berupa dana, fasilitas penunjang maupun sumber daya manusia yang ada.

Hak untuk mendapatkan pelayanan kesehatan yang berkualitas merupakan salah satu hak dasar bagi warga negara. Seperti tertuang dalam Undang-Undang Dasar 1945 pasal 28 ayat (1) dan UndangUndang Kesehatan Tahun 1992 tentang kesehatan yang mengatakan bahwa hak untuk mendapatkan pelayanan kesehatan merupakan salah satu hak dasar rakyat. Namun pada kenyataannya, berbagai data menunjukkan bahwa sebagian besar masyarakat, khususnya penduduk miskin di Indonesia masih belum mendapat pelayanan kesehatan yang memadai. Ini diakibatkan karena rendahnya status kesehatan masyarakat miskin.
Keterbatasan ini disebabkan oleh berbagai kendala antara lain kendala biaya, sosial budaya dan geografi. Beberapa kendala tersebut merupakan permasalahan yang dihadapi bagi mereka yang hidup dalam jurang kemiskinan, kehidupan yang penuh dengan segala keterbatasan ekonomi, social, budaya dan rentan terhadap penyakit.

Kemiskinan problematika yang sifatnya multidimensional, karena kemiskinan tidak hanya melibatkan faktor ekonomi akan tetapi kemiskinan juga terkait pada aspek sosial, budaya, dan struktural (politik). Kemiskinan dalam dimensi ekonomi adalah dimensi yang paling jelas dimana dimensi ekonomi ini menjelma kedalam kebutuhan dasar manusia yang sifatnya material saperti sandang, pangan, perumahan, kesehatan, dll. Dari segi sosial-budaya kemiskinan memiliki ukuran yang sangat kualitatif, dan lapisan yang secara ekonomis miskin akan membentuk kantong- kantong kebudayaan yang kita sebut dengan budaya kemiskinan. Rendahnya status kesehatan penduduk miskin seperti penyakit infeksi 
yang merupakan penyebab kematian utama pada bayi dan anak-anak balita seperti ISPA, diare,tetanus noeturum, dan penyakit kelahiran lebih sering terjadi pada penduduk miskin. Penyakit lain yang banyak diderita oleh penduduk miskin adalah penyakit tuberculosis paru, malaria, dan HIV/AIDS. Rendahnya status kesehatan penduduk miskin terutama disebabkan oleh terbatasnya akses terhadap pelayanan kesehatan karena kendala goegrafis dan kendala biaya (cost barrier) (Adisasmito,2012).

Secara sosiologis Suchman mencoba mengembangkan suatu skema dan menelusuri proses pengambilan keputusan seseorang dalam menghadapi sakit melalui 5 fase : fase pertama ketika seorang merasakan sakit si penderita berusaha mengatasinya dengan obat atau cara-cara yang diketahui dari orang tuanya atau orang lain, fase kedua : apabila belum sembuh maka si penderita akan mencari nasihat kepada orang awam di sekelilingnya ini adalah tahap system pelayanan kesehatan keluarga/berobat. Dan fase ketiga adalah yakni memasuki golongan orang yang sakit, menerima peranan sebagai orang sakit, pada fase ini sipenderita mencari nasihat kepada pemberi layanan kesehatan professional, baik modern (dokter, mantra, dan sebagainya) maupun pelayanan kesehatan tradisional (dukun, sinshe, dan sebagainya) jika tidak cocok maka akan beralih ke fasilitas yang lain. Fase keempat menerima dan melakukan prosedur pengobatan. fase kelima kembali berperan sebagai orang normal apabila ia sembuh dari penyakitnya (Notoadmojo,2010).

Kosa dan Robertson dalam Marimbi (2009), mengatakan bahwa perilaku kesehatan individu cenderung dipengaruhi oleh kepercayaan orang yang bersangkutan terhadap kondisi kesehatan yang diinginkan dan kurang berdasarkan pada pengetahuan biologi. Memang kenyataannya demikian, tiap individu mempunyai cara yang berbeda dalam mengambil tindakan penyembuhan atau pencegahan yang berbeda meskipun gangguan kesehatannya yang sama. Pada umumnya tindakan yang diambil berdasarkan penilaian individu atau mungkin dibantu oleh orang lain terhadap gangguan tersebut. Penilaian semacam ini menunjukkan bahwa gangguan yang dirasakan individu menstimulasikan dimulainya suatu proses social psikologis. Proses semacam ini menggambarkan berbagai tindakan yang dilakukan si penderita mengenai gangguan yang dialami dan merupakan bagian integral interaksi social pada umumnya.

Gambaran di atas memperlihatkan betapa pentingnya pemenuhan kebutuhan kesehatan bagi masyarakat miskin namun sangat sulit bagi mereka untuk memenuhi salah satu aspek kehidupan tersebut di tengah keterbatasan ekonomi sehingga sangatlah menarik untuk melihat bagaimana tindakan dan perilaku masyarakat miskin dalam dalam hal penggunaan dan pemanfaatan fasilitas/pelayanan kesehatan yang beragam. Dalam penelitian ini akan menggambarkan tentang faktor-faktor yang mempengaruhi pelayanan kesehatan masyarakat di wilayah pemukiman kumuh.

Tujuan penelitian ini adalah untuk menggambarkan pemamfaatan pelayanan kesehatan bagi masyarakat di pemukiman kumuh dan juga menggambarkan faktorfaktor yang berpengaruh terhadap pelayanan kesehatan bagi masyarakat pemukiman kumuh di kelurahan Karuwisi Kecamatan Panakukkang Kota Makassar.

\section{METODE PENELITIAN}

\section{Lokasi dan Rancangan Penelitian}

Lokasi penelitian ini berada dalam wilayah Kelurahan Karuwisi Kecamatan Panakukkang Kota Makassar. Penelitian yang berlangsung dari bulan Januari hingga Maret 2014 merupakan penelitian kualitatif dengan jenis penelitian studi kasus, yang bertujuan untuk mendapatkan data dan informasi sebanyak mungkin tentang masalah pokok yang dibahas. Sedangkan tipe penelitian adalah deskriptif, yaitu tipe penelitian yang bertujuan untuk menggambarkan secara obyektif dan apa adanya tentang faktorfaktor yang berpengaruh terhadap pelayanan kesehatan di wilayah 
pemukiman kumuh sesuai dengan fakta yang ditemukan di lapangan.

\section{Informan}

Informan peneltian ini adalah masyarakat miskin yang bermukim di wilayah pemukiman kumuh. Informan dalam hal ini terdiri dari profesi pemulung, sopir angkutan, tukang becak/tukang bentor.

\section{Metode Pengumpulan Data}

Pengumpulan data dilakukan oleh peneliti dengan menggunakan metode, wawancara mendalam (indepth interview). Observasi yakni pengumpulan data pendukung yang dilakukan dengan cara peneliti mengamati aktivitasaktivitas yang dilakukan oleh objek penelitian dan juga pengumpulan data dengan menggunakan studi dokumen yakni difokuskan pada data-data yang diperoleh dari surat kabar, kantor pemerintah, Dinas social dan instansi atau lembaga terkait.

\section{HASIL DAN PEMBAHASAN}

Seluruh informan dalam mengambil keputusan dalam menghadapi gejala sakit/ penyakit dengan cara yang berbeda-beda seperti ketika mereka salah satunya yakni mereka melakukan tindakan diam dengan asumsi bahwa hal tersebut hanyalah gangguan ringan saja atau tidak membahayakan namun setelah merasakan sakit dan hal tersebut sudah mengganggu aktifitas maka barulah mereka akan melakukan tindakan pengobatan seperti dengan membeli obat di warung atau apotek atau membuat ramuan-ramuan obat tradisional, atau bahkan mereka melakukan eksperimen sendiri untuk mencoba mengobati penyakitnya dengan melakukan tindakan menggunakan caracara yang tidak rasional seperti penyakit gatal-gatal, mereka obati dengan cara mengoleskan balsem, dan ada juga yang mengalami gangguan di perut pasca melahirkan itu mereka obati dengan cara diurut, adapun ke dukun, yang hanya diberikan air dan dioleskan minyak tanah di daerah perut yang sakit oleh dukun tersebut namun sembuh.

Dan jika penyakit atau gejala yang dirasakan itu berlanjut maka mereka akan melakukan pemeriksaan ke layanan kesehatan baik layanan kesehatan modern maupun tradisional, bahkan ada juga yang berkonsultasi bukannya kedokter akan tetapi konsultasi dengan apoteker.

Beragam respon masyarakat miskin dalam menghadapi penyakit, namun dalam hal menggunakan pelayanan kesehatan modern merupakan tindakan terakhir atau mereka lakukan jika usaha yang dilakukan sebelumnya sudah tidak berhasil. Hal tersebut mereka lakukan karena mereka sangat percaya diri dan merasa bahwa berdasarkan pengalaman, mereka yakin dapat mendatangkan kesembuhan dan juga secara psikologis mereka tidak senang berhubungan dengan paramedik/dokter atau pelayanan kesehatan moderen ini disebabkan oleh ada sebuah ketakutan ketika dilakukan diagnosa penyakit dan ternyata Ia mengetahui penyakitnya.

Beradasarkan hasil wawancara informan sebenarnya tidak mengerti tentang kondisi penyakit yang di derita. Terkadang mereka hanya memberikan persepsi sendiri terhadap penyakit yang mereka derita. Seperti yang telah diungkapkan sebelumnya bahwa terdapat beberapa informan tidak tertarik untuk memamfaatkan pelayanan kesehatan moderen karena mereka takut akan hasil diagnosis, mereka takut ketika Ia menemukan atau mengetahui tingkat keparahan penyakit yang diderita.

Beberapa dari informan lebih memilih untuk memanfaatkan pelayanan kesehatan tradisional seperti pelayanan kesehatan tradisional keterampilan. Dengan menggunakan tukang urut telah menyembuhkan penyakit yang diderita. Mereka tidak begitu mengerti dengan metode pengobatan moderen yang menggunakan beragam macam alat untuk mendiagnosis penyakit.

Kesehatan bagi masyarakat kumuh sangatlah penting mengingat mereka adalah masyarakat yang rentan terhadap penyakit. Hal ini disebabkan oleh lingkungan tempat tinggal mereka yang tidak layak dalam pemeliharaan kesehatan masyarakat karena dikelilingi oleh lingkungan yang kotor dan semrawut. Bagi masyarakat kumuh kehadiran 
program jaminan kesehatan masyarakat adalah program yang sangat membantu dalam pemeliharaan kesehatan keluarga mereka. Program jaminan kesehatan bagi masyarakat miskin sangat dimanfaatkan oleh masyarakat namun terkait dalam hal birokrasi pengurusannya atau prosedur pemeriksaannya mereka berharap bisa langsung untuk ke unit pelayanan kesehatan yang dituju seperti rumah sakit atau dokter spesialis dengan tidak lagi harus terlebih dahulu mengambil atau meminta rujukan dari puskesmas atau dari dokter umum. Jaminan kesehatan merupakan sistem yang telah berdiri sejak lama dan sangat diperlukan oleh masyarakat. Jaminan kesehatan merupakan pendorong pembangunan dan strategi penting dalam penanggulangan kemiskinan.

Kebutuhan akan pelayanan kesehatan bagi masyarakat sangat tinggi apalagi dalam konteks kehidupan sekarang, seperti yang kita ketahui perkembangan ilmu pengetahuan dan teknologi serta informasi telah mengalami kemajuan yang pesat. Dalam kondisi tersebut itulah yang merubah pola pikir masyarakat lebih banyak menggunakan pelayanan kesehatan moderen dan bahkan menggunakan pelayanan kesehatan private medicine.

Dari hasil wawancara mendalam yang dilakukan peneliti ditemukan bahwa masyarakat miskin cenderung berobat di tempat pelayanan kesehatan ketika penyakit yang diderita itu sudah mengganggu aktivitas mereka atau tingkat keparahan penyakit sudah tinggi. Jika penyakit tersebut tidak mengganggu aktivitas mereka maka dapatlah dipastikan bahwa mereka tidak akan memeriksa atau mengobati penyakit tersebut.

Dalam penelitian ini memperlihatkan bahwa masyarakat miskin apabila menderita suatu penyakit maka akan melakukan tindakan sebagai berikut:

a. Tidak bertindak atau tidak melakukan apa-apa (No Action). Alasannya antara lain bahwa kondisi demikian tidak akan mengganggu aktivitas atau pekerjaan harian. Mungkin mereka beranggapan bahwa tanpa bertindak apa pun symptom atau gejala yang diderita akan lenyap dengan sendirinya. Tidak jarang pula masyarakat memprioritaskan tugastugas lain yang dianggap lebih penting daripada mengobati sakitnya. Hal ini merupakan suatu bukti bahwa kesehatan belum merupakan prioritas di dalam hidup dan kehidupannya. Alasan lain yang sering kita dengar adalah fasilitas kesehatan yang diperlukan sangat jauh letaknya, para petugas kesehatan tidak simpatik, judes, tidak responsive dan sebagainya. Dan akhirnya alasan takut dokter, takut pergi kerumah sakit, takut biaya, dan sebagainya.

b. Tindakan mengobati sendiri (self treatment atau self medication). Masyarakat tersebut sudah percaya kepada diri sendiri, dan sudah merasa bahwa berdasarkan pengalaman yang lalu usaha pengobatan sendiri sudah dapat mendatangkan kesembuhan. Hal ini mengakibatkan pengobatan ke tempat pelayanan kesehatan tidak diperlukan. Mengobati sendiri yang dilakukan masyarakat melalui berbagai cara antara lain: kerokan, pijat, membuat ramuan sendiri seperti minum jamu yang dibeli dari warung, minum obat yang dibeli bebas di warung atau apotek.

c. Mencari pengobatan ke fasilitasfasilitas pengobatan tradisional (traditional remedy). Pada masyarakat yang masih sederhana masalah sehatsakit adalah lebih bersifat budaya daripada gangguan-gangguan fisik. Identik dengan itu pencarian pengobatanpun lebih berorientasi kepada social budaya masyarakat daripada hal-hal yang dianggap masih asing. Dukun (bermacam-macam dukun) yang melakukan pengobatan yang dihasilkan adalah kebudayaan masyarakat, lebih diterima oleh masyarakat daripada dokter, mantri, bidan, dan sebagainya.

d. Mencari pengobatan ke fasilitasfasilitas pengobatan modern (profesional) yang diadakan oleh 
pemerintah atau lembaga-lembaga kesehatan swasta, yang dikategorikan ke dalam Balai Pengobatan, Puskesmas, dan rumah sakit termasuk mencari pengobatan ke fasilitas pengobatan modern yang diselenggarakan oleh dokter praktik (private medicine)

(Notoadmojo, 2010).

Weber berpendapat bahwa individu melakukan suatu tindakan berdasarkan atas pengalaman, persepsi, pemahaman dan penafsirannya atas suatu obyek stimulus atau situasi tertentu. Tindakan individu ini merupakan tindakan sosial yang rasional, yaitu mencapai tujuan atau sasaran dengan sarana-saranayang paling tepat (Ritzer, 2010).

Secara sosiologis perilaku manusia tidak bisa dipisahkan dari konteks atau setting sosialnya. Seperti adanya usaha atau keinginan secara pribadi untuk melakukan pengobatan demi untuk sehat kembali namun keterbatasan-keterbatasan seperti keterbatasan dana kembali menghalangi. Hal tersebut secara sederhana bahwa perilaku sehat bukan hanya dipengaruhi oleh dorongan yang ada di dalam diri akan tetapi dipengaruhi pula oleh setting sosial yang ada disekitarnya.

Secara sosiologis Suchman mencoba mengembangkan suatu skema dan menelusuri proses pengambilan keputusan seseorang dalam menghadapi sakit melalui 5 fase : fase pertama ketika seorang merasakan sakit si penderita berusaha mengatasinya dengan obat atau cara-cara yang diketahui dari orang tuanya atau orang lain, fase kedua : apabila belum sembuh maka si penderita akan mencari nasihat kepada orang awam di sekelilingnya ini adalah tahap system pelayanan kesehatan keluarga/berobat. Dan fase ketiga adalah yakni memasuki golongan orang yang sakit, menerima peranan sebagai orang sakit, pada fase ini si penderita mencari nasihat kepada pemberi layanan kesehatan professional, baik modern (dokter, mantri, dan sebagainya) maupun pelayanan kesehatan tradisional (dukun, sinshe, dan sebagainya) jika tidak cocok maka akan beralih ke fasilitas yang lain. Fase keempat menerima dan melakukan prosedur pengobatan. fase kelima kembali berperan sebagai orang normal apabila ia sembuh dari penyakitnya (Notoadmojo,2010).

Diantara berbagai bentuk jaminan sosial, jaminan kesehatan merupakan sistem yang telah berdiri sejak lama dan sangat diperlukan oleh masyarakat. Jaminan kesehatan merupakan pendorong pembangunan dan strategi penting dalam penanggulangan kemiskinan (suharto, 2009).

Jaminan kesehatan yang digunakan bagi masyarakat miskin merupakan salah satu faktor pendorong bagi masyarakat miskin untuk menggunakan layanan kesehatan moderen. Hal tersebut sebagaimana diungkapkan oleh Andersen dalam model system kesehatan yang menggambarkan suatu konsekuensi determinan individu terhadap pemamfaatan pelayanan kesehatan oleh keluarga dan dinyatakan bahwa hal itu bergantung pada:

a. Predisposisi keluarga yaitu dimana terdapat kecenderungan yang berbeda didalam penggunaan pelayanan kesehatan, seperti: ciri-ciri demografi, struktur sosial, keyakinan terhadap mamfaat pelayanan kesehatan. Variabel ini tidak serta merta berpengaruh langsung terhadap pemamfaatan jasa pelayanan kesehatan akan tetapi sebagai faktor pendorong untuk menimbulkan hasrat guna memamfaatkan pelayanan kesehatan.

b. Kemampuan untuk melaksanakannya.

c. Kebutuhan terhadap jasa pelayanan. Faktor predisposisi dan faktor yang memungkinkan untuk mencari pengobatan dapat terwujud didalam tindakan apabila itu dirasakan sebagai kebutuhan. (Sudarma,2012).

Menurut Gasperz bahwa terdapat beberapa dimensi mutu yang harus diperhatikan dalam pelayanan yaitu ketepatan waktu pelayanan, kesopanan dan keramahan dalam memberikan pelayanan, tanggung jawab, kelengkapan, kemudahan mendapat pelayanan, dan 
atribut pendukung pelayanan lainnya (Bustami, 2011).

Dewasa ini tampak kecenderungan bahwa pola penyakit telah berubah. Orang mencari pertolongan medis bukan lagi semata-mata karena takut mati, melainkan karena ingin agar perkerjaannya seharihari tidak terganggu (Muzaham,2007).

Tindakan manusia dipahami sebagai perbuatan prilaku atau aksi yang dilakukan oleh manusia untuk mencapai tujuan tertentu. Tindakan pengobatan yang dilakukan oleh informan merupakan keputusan yang dilahirkan dari sebuah interaksi sosial dengan lingkungannnya sehingga hal tersebut mendasari terjadinya tindakan sosial. Dalam teori tindakan sosial rasional instrumental Max Weber yakni tindakan yang memperhitungkan kesesuaian antara cara dan tujuan yang dengan mempertimbangkan efisiensi dan efektivitas (kemudahan dan kehematan) dari sejumlah pilihan tindakan, sehingga tindakan tersebut lebih menekankan pada rasio (akal) sebagai alat yang digunakan untuk mendasari tindakan tersebut, yang selanjutnya diikuti oleh sejumlah tujuantujuan yang ingin dicapai. Dan juga beberapa informan melakukan pengobatan dengan cara tradisional seperti menggunakan resep menurut pengalaman atau kebiasaan dari keluarga secara turun temurun, atau berobat di kampung baik minum obat racikan atau jamu dan juga dengan diurut. Tindakan tersebut termasuk dalam tindakan sosial tradisional oleh Max Weber yakni tindakan sosial yang tidak memperhitungkan aspek rasional atau perhitungan-perhitungan tertentu tetapi lebih menekankan pada aspek kebiasaan-kebiasaan atau adat istiadat yang berlaku. Inti dari tindakan ini adalah faktor kebiasaan atau tindakan yang sudah menjadi kebiasaan yang berulang-ulang (Setiadi \& Kolip,2011).

\section{KESIMPULAN}

Berdasarkan pembahasan diatas dapat disimpulkan bahwa bagi masyarakat pemukiman kumuh, cenderung tidak melakukan tindakan apapun apabila selama gejala/penyakit yang diderita tidak menganggu aktivitas mereka. Mereka menggunakan layanan kesehatan moderen maupun juga tradisional dalam mengobati penyakit mereka. Respon masyarakat terhadap gejala atau penyakit yang dialami dengan bermacam-macam yakni dengan no-action, self treatment, traditional remedy, layanan kesehatan moderen/privat medicine. Masyarakat pemukiman kumuh cenderung memiliki persepsi sendiri terhadap gejala penyakit yang dialami, dan jaminan kesehatan menjadi pendorong dalam penggunaan pelayanan kesehatan moderen. Sehingga kemudahan tersebut yang membuat pelayanan kesehatan moderen selalu menjadi kebutuhan oleh masyarakat miskin.

\section{SARAN}

Hal yang dapat disarankan yaitu peningkatan peran pemerintah dalam peningkatan taraf hidup masyarakat khususnya dari aspek kesehatan masyarakat miskin serta perlunya peningkatan pelayanan jaminan kesehatan bagi masyarakat miskin dan penelitian ini dapat dijadikan referensi bagi penelitian selanjutnya.

\section{DAFTAR PUSTAKA}

Adisasmito, W. 2012. Sistem Kesehatan. Jakarta: Raja Grafindo Persada.

Bustami. 2011. Penjamin Mutu Layanan Kesehatan dan Akseptabilitasnya. Jakarta: Erlangga.

Marimbi, H. 2009. Sosiologi Dan Antropologi Kesehatan. Yogyakarta: Nuha Medika.

Muzaham, F. 2007. Memperkenalkan Sosiologi Kesehatan. Jakarta: Universitas Indonesia (UI-Press).

Moleong, L.J. 2006. Metodologi Penelitian Kualitatif. Bandung: PT Remaja Rosdakarya.

Notoadmodjo, Soekidjo. (2010). Ilmu Perilaku Kesehatan. Jakarta: Rineka Cipta.

Ritzer, G. 2010. Sosiologi Ilmu Pengetahuan Berparadigma Ganda. Jakarta: Rajagrafindo persada.

Setiadi, E., \& Kolip, U. 2011. Pengantar Sosiologi; pemahaman fakta dan gejala permasalahan sosial: teori 
aplikasi dan pemecahannya. Jakarta: Kencana.

Sudarma, M. 2012. Sosiologi Untuk Kesehatan. Jakarta: Salemba Medika.

Suharto, E. 2009. Kemiskinan Dan Perlindungan Sosial Di Indonesia ; Menggagas Model Jaminan Sosial Universal Bidang Kesehatan. Bandung: Alfabeta. 